\title{
PESANTREN DAN PENANAMAN SIKAP ANTI KORUPSI
}

\author{
Tamrin Fathoni \\ Institut Agama Islam Sunan Giri (INSURI) Ponorogo \\ Email: Tam2fiana@gmail.com
}

\begin{abstract}
The purpose of this study is to explore the role of pesantren in instilling anti-corruption attitudes. Pesantren is empirically known as a successful institution in developing quality education, especially in the field of religion. In the midst of a number of compliments received from pesantren, there is criticism that must reflect the pesantren, that pesantren are considered to have not succeeded in perfectly educating students who have strong personalities in anti-corruption. That criticism is not without foundation. The ministry of religion which incidentally is the headquarters of the students, is also known as one of the ministries which often ministers stumble over corruption cases. Even though they are not a few who in their daily lives work as preachers and obligatory worshipers, and can even be categorized as scholars. This study uses qualitative research library type. Data collection by identifying discourses from books, papers or articles, journals, newspapers, internet (websites), and other information that is still related to pesantren studies. Data analysis uses descriptive analysis and critical analysis. Descriptive analysis is collecting and compiling data then the data is analyzed. Meanwhile, critical analysis is the interpretation of the text and addressing the meaning behind events scientifically. The results showed the need for pesantren stakeholders to reaffirm the pesantren culture to instill anti-corruption in their students. especially through his students. Because students with their pesanten culture (a) have a simple tradition of life an absolute requirement to be a pioneer of anti-corruption; (b) has strong religious insight, and (c) deep-rooted tradition amar ma' ruf nahi munkar.
\end{abstract}

Keywoards; Culture, Pesantren, Corrupti

\section{PENDAHULUAN}

Pesantren secara empiris dikenal sebagai institusi yang sukses dalam membangun pendidikan yang berkualitas, khususnya di bidang agama, bahkan santri madrasah diniyah yang merupakan bagian integral dari pesantren (saläf) lebih mampu membaca kitab kuning daripada lulusan peruruan tinggi Islam. Hal ini terjadi antara lain karena keikhlasan kiai dan guru yang mengajar di dalamnya dengan ikhlas. Keikhlasan santri yang belajar di pesantren tampak dengan misi menimba ilmu, bukan mencari selembar ijazah.

Kalangan intelektual muslim papan atas negeri ini yang dikenal dengan kemapanan ilmu agama yang brilian dan beberapa pemimpin pemerintahanan kesemuanya memiliki latar belakang pendidikan dasar dan lanjutan di pesantren. 
Sebut misalnya, KH Abdurrahman Wahid, KH Ma'ruf Amin, Nurcholis Madjid, bahkan sebagian besar menteri agama RI, mereka banyak yang alumni pesantren.

Di tengah sejumlah pujian yang diterima dan pencapaian nyata pesantren, ada kritik pedas yang harus menjadi refleksi lembaga ini, khususnya para kiai pengasuh. Pesantren dianggap tidak atau belum berhasil mendidik santri yang memiliki kepribadian, disiplin dan komitmen kuat di bidang anti-korupsi. Dengan kata lain, ilmu agama boleh dikatakan tinggi, rajin ibadah, akan tetapi perilaku korupsi terus berlangsung selama masih ada kesempatan.

Kritik demikian terjadi bukan karena tanpa dasar. Kementerian agama (kemenag) yang memiliki notane markas para santri, tidak lepas sebagai salah satu kementerian yang beberapa pejabat dan pegawai di dalamnya tersandung skandal korupsi, semisal Majelis hakim Pengadilan Tipikor Jakarta memvonis terdakwa Harus Hasanuddin dengan pidana penjara selama 2 tahun, sedangkan terdakwa Muh Muafaq Wirahadi dihukum penjara selama 1 tahun 6 bulan. Karena dugaan jual beli jabatan Kemenag. ${ }^{1}$

Di masa ini, semua orang (termasuk santri) berpeluang menjadi pejabat eksekutif (Kepala Desa, Bupati, Gubernur, Presiden), legislatif (DPR/DPRD), atau yudikatif (Hakim, Jaksa, Polisi). Fenomena santri yang terjangkit skandal korupsi tidak hanya terjadi di kemenag, tetapi juga merambah di kementerian lain. Tidak hanya itu, kasus tindak pidana korupsi (tipikor) yang melibatkan santri juga terjadi di lembaga legislatif baik pusat maupun daerah. Semisal Muhir, selaku anggota DPRD Kota Mataram dari Fraksi Golkar, terdakwa kasus operasi tangkap tangan (OTT) dana rehabilitasi pembangunan SMP dan SMA di Kota Mataram, akhirnya divonis 2 tahun penjara dan denda Rp 50 juta oleh Majelis Hakim Tindak Pidana Korupsi (Tipikor), Pengadilan Negeri Mataram, Jumat siang (1/3/2019). ${ }^{2}$ Dengan demikian, perlu kiranya para pemangku kebijakan pesantren untuk meneguhkan kembali budaya pesantren dalam menanamkan sikap anti korupsi.

\footnotetext{
https://nasional.sindonews.com/read/1427740/13/jual-beli-jabatan-kemenag-harisdivonis-2-tahun-muafaq-15-tahun-1565180490 diakses pada tanggal 8 Agustus 2019 pukul 23.18 WIB.

2 https://regional.kompas.com/read/2019/03/02/10583881/divonis-2-tahun-muhirterdakwa-korupsi-dana-gempa-menangis?page=all diakses pada tanggal 8 Agustus 2019 pukul 23:34 WIB.
} 


\section{Pesantren dalam Diskursus Pendidikan Islam}

Perkataan pesantren berasal dari kata "santri", 3 dengan awalan "pe" di depan dan akhiran "an" berarati tempat tinggal para santri." Sedangkan asal usul kata "santri" dapat dilihat dua pendapat:

1. Pendapat yang mengatakan bahwa "santri" berasal dari perkataan "sastri", sebuah kata dari bahasa Sansekerta yang artinya "melek huruf".

2. Pendapat yang mengatakan bahwa perkataan "santri" sesungguhnya berasal dari bahasa Jawa, dari kata "cantrik", berarti "seseorang yang selalu mengikuti seseorang guru kemanapun guru menetap".

Di Indonesia istilah pesantren lebih populer dengan sebutan pondok pesantren. Lain halnya pesantren, pondok berasal dari bahasa Arab "funduq", yang berarti "hotel, asrama, rumah, dan tempat tinggal sederhana". ${ }^{5}$ Sedangkan secara terminologi pondok pesantren adalah sarana pendidikan tradisional dimana santrinya tinggal bersama dan belajar di bawah bimbingan seorang guru atau lebih yang lebih dikenal dengan sebutan Kiai. Asrama untuk santri tersebut berada dalam lingkungan komplek pesantren, dimana Kiai bertempat tinggal yang juga menyediakan masjid untuk ibadah, ruangan untuk belajar dan kegiatan lain. ${ }^{6}$

Selain itu, pondok pesantren juga diartikan sebagai lembaga tafaqquh fiddin yang mempunyai fungsi pemeliharaan, pengembangan, penyiaran dan pelestarian Islam, dari segi kemasyarakatan, menjalankan pemeliharaan dan pendidikan mental. ${ }^{7}$

1. Elemen pondok pesantren.

Ciri khas yang dimiliki pondok pesantren dengan lembaga pendidikan dalam bentuk lain adalah dengan adanya lima elemen yaitu:

a. Kiai, di daerah Sunda disebut dengan "ajengan", di daerah Madura disebut "nun" atau "bendara", disingkat "ra".

${ }^{3}$ Yasmani, Modernisasi Pesantren; Kritik Nurcholis Majid terhadap Pendidikan Islam Tradisional (Ciputat: Ciputat Press, 2002), 61.

4 Zamakhsyari Dhofier, Tradisi Pesantren (Jakarta: LP3S, 1982), 18.

5 Eka Srimulyani, Women From Traditional Islamic Education Institutional In Indonesia, (Amsterdam: Amsterdam University, $\mathrm{tt}$ ), 40.

6 Zamakhsyari Dhofier, Tradisi Pesantre, 18.

7 M. Dawam Raharjo, Pesantren dan Pembaharuan, (Jakarta: LP3ES, 1974), 83. 
b. Masjid atau surau, digunakan sebagai tempat beribadah dan belajar mengajar santri.

c. Pondok, merupakan tempat tinggal kiai bersama para santri.

d. Santri, biasanya santri dikelompokkan menjadi dua kelompok yaitu:

1) Santri mukim yaitu, santri yang berasal dari daerah jauh dan menetap dalam pondok pesantren

2) Santri kalong yaitu, santri yang berasal dari daerah pesantren, biasanya dia tidak menetap dan pulang kerumah masing-masing setiap selesai mengikuti pelajaran.

3) Kitab-kitab klasik (kitab kuning), yaitu kitab-kitab yang dikarang oleh ulama-ulama terdahulu, mengenai berbagai ilmu pengetahuan agama Islam dalam bahasa Arab. ${ }^{8}$

2. Tujuan terbentuk pondok pesantren.

a. Tujuan umum.

Membimbing anak didik untuk menjadi manusia yang berkepribadian Islam yang dengan ilmu agamanya ia sanggup menjadi mubalig Islam dalam masyarakat sekitar melalui ilmu dan amalnya.

b. Tujuan khusus.

Mempersiapkan para santri untuk menjadi orang alim dalam ilmu agama yang diajarkan oleh kiai yang bersangkutan serta mengamalkannya dalam masyarakat. ${ }^{9}$

3. Bentuk-bentuk pesantren

Seiring dengan laju perkembangan masyarakat, maka pendidikan pesantren baik tempat, bentuk, hingga substansinya telah jauh mengalami perubahan. Pesantren tidak lagi sesederhana. Pesantren dewasa ini dapat diklasifikasikan menjadi pesantren salāf, khalāf, kilat dan terintegrasi.

a. Pesantren salāfi yaitu pesantren yang tetap mempertahankan pelajarannya dengan kitab-kitab klasik dan tanpa diberikan pengetahuan umum. Metode pembelajarannya sorogan dan weton.

8 Abdurahman Wahid, Menggerakkan Tradisi Pesantren, (Yogyakarta: LKIS, 2007), 4.

${ }^{9}$ Hasbullah, Sejarah pendidikan Islam di Indonesia; Lintasan Sejarah dan Perkembangan (Jakarta: Raja Grafindo Persada, 1995), 25. 
b. Pesantren khaläfi yaitu pesantren yang menerapkan sistem pengajaran klasikal (madrāsi). Memberikan ilmu umum dan ilmu agama dan juga memberikan pendidikan keterampilan.

c. Pesantren kilat yaitu pesantren yang berbentuk semacam training dalam waktu relatif singkat dan biasanya dilaksanakan pada waktu libur sekolah.

d. Pesantren terintegrasi yaitu pesantren yang lebih menekankan pada pendidikan vokasional atau kejujuran sebagaimana balai latihan kerja di Departemen Tenaga Kerja dengan program terintegrasi. ${ }^{10}$

4. Ciri pendidikan pesantren

Pendidikan pesantren merupakan pendidikan yang mempunyai ciri khas tersendiri, ciri-ciri pendidikan pesantren adalah sebagai berikut:

a. Adanya hubungan yang akrab antara santri dengan kiai

b. Kepatuhan santri kepada kiai

c. Hidup hemat dan sederhana benar-benar diwujudkan dalam lingkungan pesantren

d. Kemandirian amat terasa di pesantren.

e. Jiwa tolong-menolong dan suasana persaudaraan sangat mewarnai pergaulan di pesantren

f. Disiplin sangat dianjurkan di pesantren

g. Berani menderita untuk mencapai suatu tujuan merupakan salah satu segi pendidikan yang diperoleh santri di pesantren

h. Pemberian ijazah. ${ }^{11}$

5. Prinsip-prinsip pendidikan pesantren

Pesantren memiliki prinsip-prinsip utama dalam menjalankan pendidikannya. Setidaknya ada dua belas prinsip yang dipegang teguh pesantren. Yaitu:
a. Theocentric
b. Sukarela dalam pengabdian
c. Kearifan

10 M. Akhyar Muslimin, Jejak-Jejak Islam di Indonesia, (Malang: UMM Press, 2006), 101-102.

11 Abudin Nata, Sejarah Pertumbuhan dan Perkembangan Lembaga-Lembaga Pendidikan Islam di Indonesia, (Jakarta: Grafindo Persada), 118-119. 
d. Kesederhanaan

e. Kolektivitas

f. Mengatur kegiatan bersama

g. Kebebasan terpimpin

h. Kemandirian

i. Pesantren adalah tempat mencari ilmu dan mengabdi

j. Mengamalkan ajaran agama

k. Belajar di pesantren bukan untuk mencari ijazah

1. Restu kiai, artinya semua perbuatan yang dilakukan oleh setiap warga pesantren sangat bergantung pada kerelaan dan doa dari kyai. ${ }^{12}$

6. Fungsi pesantren

Ada beberapa fungsi pondok pesantren, diantara fungsi pesantren antara lain adalah

a. Pesantren sebagai lembaga pendidikan

Fungsi pesantren sebagai lembaga pendidikan terletak pada kesiapan pesantren dalam menyiapkan diri untuk ikut serta dalam pembangunan di bidang pendidikan dengan jalan adanya perubahan sistem pendidikan sesuai dengan arus zaman dan era teknologi secara global. Hal ini terlihat bahwa pesantren terus menyesuaikan diri dengan lingkungan pendidikan dengan prinsip masih tetap dalam kawasan prinsip agama.

b. Pesantren sebagai lembaga dakwah

Keberadaan pesantren ditengah masyarakat merupakan suatu lembaga yang bertujuan menegakkan kalimat Allah Swt dalam pengertian penyebaran agama Islam dengan sebenarnya. ${ }^{13}$ Kiprah pesantren sebagai lembaga dakwah di masyarakat merupakan suatu aktivitas menumbuhkan kesadaran beragam dengan melaksanakan ajaran-ajaran dari pesantren secara konskuen sebagai pemeluk agama. Karena tujuan pendirian pesantren adalah untuk memberikan ilmu-ilmu agama secara komperhensif. Kehadiran pesantren adalah sebagai lembaga dakwah Islamiyah.

12 Ibid., 113.

13 Ibid., 37-39. 
Kegiatan-kegiatan dakwah yang dikembangkan pesantren dengan berbagai cara diantara sebagai berikut;

1) Pembentukan kelompok-kelompok dakwah pengajian bagi masyarakat. Fungsi Pesantren sebagai lembaga pendidikan terletak pada kesiapan pesantren guna menyiapkan diri untuk ikut serta dalam pembangunan di bidang pendidikan dengan jalan adanya perubahan sistem pendidikan sesuai dengan arus perkembangan zaman dan erat teknologi secara global. Hal ini juga terlihat bahwa sistem pendidikan pondok pesantren terus menyesuaikan diri dengan lingkungan pendidikan dengssan prinsip-prinsip tetap dalam kawasan prinsip agama.

2) Memadukan kegiatan dakwah melalui kegiatan masyarakat. Keberadaan pesantren di tengah masyarakat merupakan suatu lembaga yang bertujuan menegakkan kalimat Allah Swt dalam pengertian penyebaran ajaran agama Islam agar pemeluknya memahami Islam dengan sebenarnya. Oleh karena itu, kehadiran pesantren sebenarnya dalam rangka dakwah Islamiyah. Hanya saja kegiatan-kegiatan pesantren dapat dikatakan sangat beragam dalam memberikan pelayanan untuk masyarakatnya.

3) Pesantren sebagai lembaga sosial, fungsi pesantren sebagai lembaga sosial menunjukkan keterlibatan pesantren dalam menangani masalah-masalah sosial yang dihadapi oleh masyarakat. Masalah-masalah sosilal yang dimaksud oleh pesantren pada dasarnya bukan saja terbatas pada aspek duniawi, melainkan juga ukhrawi. Berupa bimbingan rohani, menurut Sudjoko Prasodjo merupakan jasa besar pesantren terhadap masyarakat desa. Pertama, kegiatan tablig kepada masyarakat yang dilakukan dalam kompleks pesantren. Kedua, majelis taklim atau pengajian yang bersifat pendidikan umum. Ketiga, bimbingan hikmah berupa nasehat kiai pada orang yang datang untuk diberi amalan-amalan apa yang harus dilakukan untuk mencapai suatu hajat, nasehat-nasehat agama dan sebagainya. ${ }^{14}$

14 M. Bahri Ghazali, Pesantren Berwawasan Lingkungan, (Jakarta: CV. Prasasti, 2003), 40. 
Dari beberapa fungsi pesantren di atas yang tidak kalah pentingnya pesantren dengan teologi yang dianutnya hingga kini ditantang untuk menyikapi globalisasi secara kritis dan bijak. Pesantren harus mampu mencari solusi yang benar-benar mencerahkan sehingga pada satu sisi dapat menumbuh kembangkan kaum santri yang memiliki wawasan luas yang tidak gampang menghadapi modernitas dan sekaligus tidak kehilangan identitas dan jati dirinya dan pada sisi lain dapat mengantarkan masyarakat menjadi komunitas yang menyadari tentang persoalan yang dihadapi dan mampu mengatasi dengan penuh kemandirian dan keadaban. ${ }^{15}$

\section{Budaya dan Sinergi Dinamika Sosial}

Ada banyak sekali pengertian mengenai budaya. A.L. Kroeber dan C. Kluckhohn menghimpun sebanyak 160 lebih mengenai definisi kebudayaan tersebut dalam buku mereka berjudul Cultture, a Crittical Review of Concepts and Defnittions.

Secara etimologis, Koentjaraningrat menyatakan bahwa kata "budaya" berasal dari kata "budhayah", bahasa Sanskerta, yang merupakan bentuk jamak dari kata "buddhi" yang berarti "budi atau akal". Dengan demikian, kebudayaan dapat dikatakan "hal-hal yang berkaitan dengan budi dan akal". ${ }^{16}$ Karena ia berkaitan dengan budi dan akal manusia, maka wilayahnya menjadi demikian luas. Koentjaraningrat kemudian menyatakan bahwa kebudayaan paling sedikit mempunyai tiga wujud, yaitu:

1. Wujud kebudayaan sebagai suatu kompleks dari ide-ide, gagasan, nilai-nilai, norma peraturan dan sebagainya.

2. Wujud kebudayaan sebagai suatu kompleks aktivitas, kelakuan berpola dari manusia dalam masyarakat.

3. Wujud kebudayaan sebagai benda-benda hasil karya manusia. ${ }^{17}$

Berdasarkan pengertian tentang budaya yang demikian, maka setiap individu, komunitas, dan masyarakat melalui kreasinya pun bisa menciptakan sebuah budaya tertentu Ketika kreasi yang diciptakan itu kemudian secara

15 Abd A'la, Pembaruan Pesantren, (Jakarta: Pustaka Pesantren, 2006), 7-9.

${ }^{16}$ Koentjaraningrat, Kebudayaan, Mentalitetdan Pembangunan, (Jakarta: Gramedia, 1976), 19.

17 Ibid., 15. 
berulang, bahkan kemudian menjadi kesepakatan kolektif maka pada saat itu kreasi itu telah menjelma menjadi sebuah budaya. Salah satu komunitas yang mampu membentuk budaya yang khas adalah pesantren.

Sebagai warisan budaya Islam di Indonesia, pesantren bahkan bukan hanya lembaga pendidikan, melainkan kebudayaan Islam itu sendiri. Hal ini terkait dengan corak dasar peradaban Islam yang memuliakan pendidikan. Oleh karenanya, pendidikan tidak menjadi proses didaktik an sich, melainkan mode of being dari keberislaman.

Ada nilai-nilai yang dapat dilihat dari wujud budaya pesantren. Pertama, nilai keilmuan. Santri sejak awal masuk pesantren telah digodok belajar ilmu-ilmu dasar Islam. Pesantren telah mengajarkan kitab-kitab klasik, yang berbahasa Arab dan tanpa harakat. Dalam hal ini santri diajari dari dasar Naḥwu Șarf sampai bisa baca sekaligus mampu menggali makna dari kitab-kitab gundulan. Dari keahlian ini mereka dapat memperdalam ilmu yang berbasis pada kitab-kitab klasik melalui proses panjang dengan pola umum pembelajarannya antara lain sebagai berikut: (1). Hafalan (Tahfiz); (2). Hiwwār atau Musyawarah; (3). Mużākarah (bahı̀su almasāil); (4). Fatḥu al-kutub (baca kitab); (5). Muqāranah (perbandingan); dan (6). Muḥāwarah atau muḥādasah (latihan bercakap/ pidato). Dengan demikian terbangun karakter bidang keilmuan yang benar-benar kuat, sehingga ilmu yang diperoleh dipahami dan untuk selanjutnya langsung diamalkan. ${ }^{18}$

Kedua, nilai akhlak, akhlak merupakan pembelajaran inti yang diterapkan pesantren kepada santrinya. Karena ujuan pesantren adalah tafaqquh fi al-din (memahami agama) dan membentuk moralitas umat. Kalau diringkas penjelasan tersebut, maka dapat ditarik pemahaman bahwa pesantren bertujuan utama membentuk akhlak sebagai bidang utama dalam membangun karakter santri. ${ }^{19}$

Ketiga, nilai bidang sosial, santri termasuk bagian dari masyarakat yang memerlukan interaksi dan komunikasi sosial. Di dalam menempuh pendidikan, diberikan pendidikan yang dilandasi tafaqquh fi al-dìn (memahami agama) dan akhlak karimah dan pendidikan yang mengarah kepada karakter santri bidang

${ }^{18}$ H. M. Amin Haedari, Masa Depan Pesantren, (Jakarta: IRD Press, 2004), 21.

19 Ainur Rofik, Pembaruan Pesantren (Respon terhadap Tuntutan Transformasi Global), (STAIN: Jember Press, 2012), 50. 
sosial. bahwa pesantren adalah satu kesatuan integral yang tidak lepas dari realitas objektif kemasyarakatan agar mampu menjawab tantangan zaman. Sehingga tidak heran jika di pesantren pendidikan juga mengarah kepada pembentukan karakter sosial seperti tolong menolong, rukun dan damai, penuh tanggung jawab untuk kebaikan umat, dan lain semacamnya.

Demi kebaikan umat semacam tersebut, pesantren telah menunjukkan eksistensinya sebagai lembaga pendidikan yang berhasil mendidik umat/masyarakat dengan biaya murah dengan tetap bermutu tinggi. Menurut Dawam Rahardjo dalam Haedari bahwa pesantren memiliki peran penting sebagai agen pembaharuan sosial yang paling menonjol adalah kemampuan pesantren dalam menyediakan sarana pendidikan relatif murah dan terjangkau oleh masyarakat. Bahkan seorang sosiolog Jerman bernama Mamfred Ziemiek mengungkapkan bahwa pesantren telah berhasil melaksanakan proyek sinergis antara kerja dan pendidikan serta berhasil dalam membina lingkungan desa berdasarkan struktur budaya dan sosial. ${ }^{20}$

\section{Korupsi}

Istilah korupsi berasal dari kata Latin "corruptius" atau "corruptio". Kata "corruptus" berarti "to abuse" (menyalahgunakan) atau "to deviate" (menyimpang). Dalam bahasa Indonesia, secara sederhana kata "korupsi" dapat diartikan perbuatan menggunakan kekuasaan untuk kepentingan sendiri seperti menggelapkan uang atau menerima uang suap. Berdasarkan pengertian sederhana ini, korupsi mengacu pada upaya yang dilakukan untuk mendapatkan uang secara tidak sah.

Namun secara lebih luas, Kementerian Pendidikan sebagaimana dikutip oleh Wibowo mendefinisikan bahwa "korupsi" sebagai istilah yang mengacu pada pemakaian dana pemerintah untuk tujuan pribadi, keluarga atau kelompok yang tidak hanya menyangkut korupsi moneter yang konvensional, melainkan juga korupsi politik dan administratif. Kartono mendefinisikan korupsi sebagai tingkah laku yang menggunakan wewenang dan jabatan guna mengeruk 
keuntungan pribadi dengan merugikan kepentingan umum dan negara. ${ }^{21}$ Berdasarkan definisi di atas, dapat dikatakan bahwa seorang yang memanfaatkan wewenang, jabatan, kedudukan, dan sumber pemerintah atau negara untuk kepentingan pribadi dapat dikategorikan sebagai koruptor.

Dalam kehidupan sehari-hari, korupsi materi sering diistilahkan dengan pengambilan barang atau harta milik negara secara tidak jujur dan di luar ketentuan yang diperbolehkan. Dengan demikian, istilah korupsi tidak ada bedanya dengan pencurian dan perampokan yang kerap dilakukan oleh para penjahat atau residivis. Korupsi, penipuan, dan pencurian memiliki kesamaan dalam hal pengambilan secara tidak sah, merugikan orang lain, amoral, bertentangan dengan norma agama dan hukum. Hanya saja, korupsi merupakan istilah yang lebih halus dan biasanya dilakukan oleh orang-orang berpendidikan, pegawai pemerintah, dan orang-orang yang punya kedudukan dan jabatan. Sedangkan penipuan dan pencurian kerap kali dilakukan oleh para residivis, penjahat, dan orang-orang yang tidak punya kedudukan dan jabatan di institusi atau lembaga kepemerintahan.

Komisi Pemberantasan Korupsi (KPK) mendefinisikan korupsi sebagai penyalahgunaan wewenang yang secara gamblang dijelaskan dalam 13 pasal UU No. 31 Tahun 1999 jo. UU No. 20 Tahun 2001. Berdasarkan UU tersebut, tindak pidana korupsi meliputi 30 bentuk/jenis tindak pidana yang secara umum dapat dikelompokkan menjadi tujuh macam yaitu:

1. Kerugian negara ( 2 bentuk dalam 2 pasal);

2. Suap menyuap (12 bentuk dalam 6 pasal);

3. Penggelapan dalam jabatan (5 bentuk dalam 3 pasal);

4. Perbuatan pemerasan ( 3 bentuk dalam 1 pasal);

5. Perbuatan curang ( 6 bentuk dalam 2 pasal);

6. Benturan kepentingan dalam pengadaan (1 bentuk dalam 1 pasal); dan

7. Gratifikasi (1 bentuk dalam 1 pasal). ${ }^{22}$

${ }^{21}$ Kartini Kartono, Patologi Sosial, jilid 1, (Jakarta: RajaGrafindo Persada, 2013), 90.

22 Tim Penyusun, Memahami untuk Membasmi; Buku Saku untuk Memahami Tindak Pidana Korupsi, (Jakarta: Komisi Pemberantasan Korupsi, 2006), 4-5. 
Ketujuh klasifikasi tersebut merupakan tindak pidana yang terkait langsung dengan korupsi. Di samping itu, juga ada beberapa tindak pidana lain yang secara tidak langsung berkaitan dengan tindak pidana korupsi, yaitu:

1. Merintangi pemeriksaan perkara korupsi

2. Tidak memberikan keterangan atau memberikan keterangan yang tidak benar

3. Bank yang tidak memberikan keterangan rekening tersangka

4. Saksi atau ahli yang tidak memberi keterangan atau memberi keterangan palsu

5. Orang yang memegang rahasia jabatan tidak memberikan keterangan atau memberikan keterangan palsu

6. Saksi yang membuka identitas pelapor.

Sebagai penyakit masyarakat, korupsi memberikan banyak dampak negatif dalam berbagai sektor kehidupan masyarakat. Mc. Mullan sebagaimana dikutip oleh Wibowo menyebutkan beberapa dampak negatif dari korupsi, diantaranya:

1. Ketidakefisienan

2. Ketidakstabilan

3. Rakyat tidak mempercayai pemerintah

4. Terjadi pemborosan sumber-sumber dan pemasukan negara

5. Tidak mendorong perusahaan untuk berusaha terutama perusahaan asing

6. Ketidakstabilan politik

7. Pembatasan dalam kebijaksanaan pemerintah, dan tidak represif. ${ }^{23}$

Suyuthi Pulungan juga memberikan penjelasan bahwa faktor penyebab terjadinya tindakan korupsi bisa bersifat internal maupun eksternal. Faktor internal meliputi sifat tamak yang ada dalam diri manusia, moral yang tidak kuat menahan godaan di depan mata, dan penghasilan yang kurang memadahi. Sedangkan penyebab eksternal adalah situasi lingkungan atau adanya peluang, dan kesempatan yang sangat mendukung. ${ }^{24}$

${ }^{23}$ Agus Wibowo, Pendidikan Anti Korupsi di Sekolah, (Yogyakarta: Pustaka Pelajar, 2013), 26.

24 Suyitno, Korupsi Hukum dan Moralitas Agama; Mewacanakan Fiqih Anti Korupsi, (Yogyakarta: Gama Media, 2006), 205. 


\section{METODE}

Penelitian ini adalah penelitian kualitatif dengan jenis library research. Pengumpulan data dengan mengidentifikasi wacana dari buku, makalah atau artikel, jurnal, koran, internet (web), dan informasi lain yang masih berhubungan dengan studi pesantren. Analisis data menggunakan analisis-deskripstif dan analisis-kritis. Analisis deskriptif yaitu mengumpulkan dan menyusun data kemudian data tersebut dianalisis. Sementara itu, analisis-kritis yaitu penafsiran pada teks dan menyikapi makna dibalik peristiwa secara ilmiah.

\section{HASIL DAN PEMBAHASAN}

\section{Meneguhkan Budaya Pesantren Guna Menanamkan Sikap Anti Korupsi}

Pesantren sejatinya memiliki potensi penting dalam rangka mengembangkan pemberdayaan masyarakat dalam konteks nasional dan global melalui peran sosial dan budaya. Peran sosial yang dimaksudkan adalah, bahwa lembaga pesantren memiliki tiga fungsi utama, yaitu: pertama, sebagai lembaga pendidikan yang menyelenggarakan pendidikan formal (madrasah, sekolah umum, dan perguruan tinggi) dan pendidikan nonformal yang secara khusus mengajarkan agama. Kedua, sebagai lembaga sosial yang egaliter, demokratis, dan tidak diskriminatif. Pesantren juga terbuka untuk masyarakat luas untuk mengonsultasikan apapun kepada kiai tentang masalah umat. Ketiga, sebagai lembaga penyiaran agama yang menjangkau semua kalangan dan wilayah terpencil sekalipun.

Oleh karena itu, pentingnya kalangan pesantren meneguhkan kembali nilai budaya yang dimilikinya dalam pemaknaan yang lebih kreatif. Salah satunya soal penanaman anti korupsi. Pesantren dengan budayanya merupakan kelompok yang paling ideal menjadi pelopor anti-korupsi, terutama melalui santrinya. Karena santri dengan budaya pesantennya (a) memiliki tradisi kehidupan yang sederhana syarat mutlak untuk menjadi pelopor antikorupsi; (b) memiliki wawasan keagamaan kuat, dan (c) tradisi amar ma'rüf nahi munkar yang mengakar. Dengan syarat selama di pesantren santri tersebut mendapat pendidikan, 
pelatihan dan keilmuan yang cukup untuk menjadi bekal dalam memerangi korupsi.

Santri bisa menjadi pelopor pemberantasan korupsi di pesantren. Secara budaya dapat dimulai dari teladan hidup sederhana dari kiai sebagai pengasuh pesantren itu sendiri. Peran kiai sebagai tokoh teladan dapat dicerminkan melalui prilakunya sebagai panutan dalam pembinaan katakter melalui pembiasaan disiplin, diantaranya disiplin beribadah, disiplin belajar, dan disiplin waktu. Sehingga, sikap dan perilaku tersebut menjadi contoh konkret dan kebiasaan bagi para santri.

Selanjutnya peran kiai juga sebagai seorang guru (pengajar). Kiai adalah tokoh yang paling dihormati dan menjadi tempat bertanya sekaligus rule model. Sebagai rule model tersebut, posisi kiai dapat ditunjukkan pada proses kegiatan pembelajaran di dalam kelas dengan memberikan contoh dengan tata cara berpakaian, adab memulai dan mengakhiri pelajaran, tata krama ketika proses pembelajaran berlangsung dan tata tertib masuk-keluar ruang belajar.

Hidup sederhana menjadi syarat mutlak untuk pembelajaran tidak melakukan korupsi. Santri harus memiliki mindset (pola pikir) dan determinasi tetap hidup sederhana walaupun kelak ia memiliki posisi ekonomi yang mapan dan berkecukupan. Kesederhanaan menjadi hal terpenting bagi santri era sekarang dan mendatang.

Selain itu, santri yang melalui pendidikan dan budayanya mempunyai peran penting untuk menduduki sebagai pemimpin atau penegak hukum sesuai kriteria yang dibutuhkan di Indonesia. Dalam menempa keilmuannya, seorang santri akan mengarungi bahtera intelektuanya di pesantren. Guna membangun kemampuan SDM santri yang berkualitas, santri dapat menempuh pendidikan secara holistik di pesantren. Kurikulum pesantren juga didesain dengan kwbutuhan santri di masa ini dan mendatang. Kurikulum agama menjai landasan pertama yang harus dikenalkan santri, maka ketiksa santri menempuh pendidikan di pesantren tentu ia akan belajar ilmu Fikih, Akhlak, Usul Fikih, Alquran, Hadis, Bahasa Arab, Nahwwu, Șarf dan masih banyak lagi. Dari sekian banyak matapelajaran di pesantren, perlu ada penekanan di bidang fikih. Suatu 
mata pelajaran yang menjelaskan halal dan haram yang pada akhinya mengerucut pada pendidikan anti korupsi.

Pesantren sebagai lembaga pendidikan Islam telah mampu berdialog dan menyerap budaya lokal nusantara. Meski kerap dianggap sebagai lembaga pendidikan tradisional, peran pesantren mempunyai kemampuan untuk menyesuaikan diri dengan perkembangan zaman. Zaman telah memaksa pesantren untuk berbenah, berubah, dan berkembang secara dinamis.

Hal yang paling utama dalam membentuk karakter santri adalah karakter calon pemimpin dan juga penegak hukum nasional yang berprinsip amar ma'rūf nahi munkar. Dari sekian banyak rumusan tentang karakter, yang tidak pernah terlewatkan ialah kejujuran. Justru di dalam masalah utama ini kita mengidap kelemahan yang merata. Sulit sekali mencari pemimpin yang jujur baik di lembaga pemerintah, perusahaan, partai politik, dan ormas, termasuk ormas agama. Yang perlu juga digarisbawahi ialah sikap adil, berani dalam memperjuangkan kebenaran, sederhana, dan peduli terhadap orang rakyat.

Terbentuknya karakter jujur dapat diaplikasikan seperti santri tidak menyontek ketika ujian berlangsung, tidak berbohong dalam ucapan maupun perbuatan, melaksanakan amanah, berani memperjuangkan kebenaran keilmuan yang dia miliki. Kemudian, santri juga bisa peduli terhadap rakyat sesuai dengan norma sosial dan agama.

Indonesia membutuhkan penegak hukum yang progresif dimana penegak hukum yang memandang bahwa hukum sendiri adalah untuk manusia. Hukum tidak ada untuk diri dan keperluannya sendiri, melainkan untuk manusia, khususnya kebahagiaan manusia. ${ }^{25}$ Hal ini sesuai dengan teori Sinzheimer yang mengatakan bahwa hukum tidak bergerak dalam ruang yang hampa dan berhadapan dengan hal-hal yang abstrak, melainkan hukum juga berada dalam suatu tatanan sosial tertentu dan manusia-manusia yang hidup. ${ }^{26}$ Semua itu dapat

\footnotetext{
${ }^{25}$ Satjipto Rahardjo, Biarkan Hukum Mengalir; Catatan Kritis tentang Pergulatan Manusia dan Hukum, (Jakarta: Penerbit Buku Kompas, 2007), ix.

${ }^{26}$ Esmi Warassih, Pranata Hukum; Sebuah Telaah Sosiologis, (Semarang: Suryandaru Utama Semarang, 2005), 3.
} 
dicapai oleh pesantren selama pesantren berupaya kembali untuk meneguhkan kembali budayanya yang sudah ada selama ini.

\section{SIMPULAN}

Upaya meneguhkan kembali pada kalangan pesantren tenang nilai budaya yang dimilikinya dalam angka penanaman anti koropsi memang suatu hal mutlak untuk dilakukan karena Pesantren dengan budayanya merupakan kelompok yang paling ideal menjadi pelopor antikorupsi, terutama melalui santrinya. Karena santri dengan budaya pesantennya (a) memiliki tradisi kehidupan yang sederhana syarat mutlak untuk menjadi pelopor antikorupsi; (b) memiliki wawasan keagamaan kuat, dan (c) tradisi amar ma'rüf nahi munkar yang mengakar. Dengan syarat selama di pesantren santri mendapat pendidikan, pelatihan dan keilmuan yang cukup untuk menjadi bekal memerangi korupsi.

\section{BIBLIOGRAFI}

Amin, HM. 2004. Masa Depan Pesantren. Jakarta IRD Press.

Bahasa. Tim Penyusun Kamus Pusat. 2008. Kamus Besar Bahasa Indonesia. Jakarta Pusat Bahasa.

Dhofier, Zamakhsyari. 1982. Tradisi Pesantren. Jakarta LP3S.

Ghazali, M. Bahri. 1976. Pesantren Berwawasan Lingkungan. Jakarta CV. Prasasti.

Haedari, H. M. Amin. 2004. Masa Depan Pesantren. Jakarta IRD Press.

Hasbullah. 1995. Sejarah pendidikan Islam di Indonesia; Lintasan Sejarah dan Perkembangan. Jakarta Raja Grafindo Persada.

https://nasional.sindonews.com/read/1427740/13/jual-beli-jabatan-kemenagharis-divonis-2-tahun-muafaq-15-tahun-1565180490 Diakses Pada Tanggal 8 Agustus 2019 Pukul 23.18 Wib.

https://regional.kompas.com/read/2019/03/02/10583881/divonis-2-tahun-muhir-terdakwakorupsi-dana-gempa-menangis?page=all Diakses Pada Tanggal 8 Agustus 2019 Pukul 23:34 Wib.

Koentjaraningrat. 1976. Kebudayaan, Mentalitet dan Pembangunan. Jakarta Gramedia. 
Kartono, Kartini. 2013. Patologi Sosial, Jilid 1. Jakarta RajaGrafindo Persada.

Muslimin, M. Akhyar. 2006. Jejak-Jejak Islam Di Indonesia. Malang UMM Press.

Nata, Abudin. Sejarah Pertumbuhan Dan Perkembangan Lembaga-Lembaga Pendidikan Islam Di Indonesia. Jakarta Grafindo Persada.

Raharjo, M. Dawam. 1974. Pesantren dan Pembaharuan. Jakarta LP3ES.

Rofik, Ainur. 2012. Pembaruan Pesantren (Respon terhadap Tuntutan Transformasi Global). STAIN Jember Press Haedari.

Penyusun. Tim, 2006. Memahami untuk Membasmi: Buku Saku untuk Memahami Tindak Pidana Korupsi. Jakarta Komisi Pemberantasan Korupsi.

Satjipto, Rahardjo. 2007. Biarkan Hukum Mengalir (Catatan Kritis Tentang Pergulatan Manusia dan Hukum). Jakarta Penerbit Buku Kompas.

Srimulyani, Eka. Tt. Women From Traditional Islamic Education Institutional In Indonesia, Amsterdam Amsterdam University.

Suyitno, 2006. Korupsi Hukum dan Moralitas Agama, Mewacanakan Fiqih Anti Korupsi.Yogyakarta Gama Media.

Wahid, Abdurahman. 2007. Menggerakkan Tradisi Pesantren. Yogyakarta LKIS.

Warassih, Esmi. 2005. Pranata Hukum: Sebuah Telaah Sosiologis. Semarang Suryandaru Utama Semarang.

Wibowo, Agus. 2013. Pendidikan Anti Korupsi di Sekolah. Yogyakarta Pustaka Pelajar.

Yasmani, Modernisasi Pesantren; Kritik Nurcholis Majid Terhadap Pendidikan Islam Tradisional, Ciputat Press: Ciputat, 2002. 